\section{Turf Nutrient Leaching and Best Management Practices in Florida}

\author{
Laurie E. Trenholm ${ }^{1,3}$ and Jerry B. Sartain ${ }^{2}$
}

ADDITIONAL INDEX WORDs. st. augustinegrass, nitrate, nonpoint source pollution, fertilizer, Stenataphrum secundatum

SUMMARY. Best management practices (BMPs) for Florida's green industries have been established since 2002. BMPs for nonagricultural industries such as commercial lawn care were developed in 2002 by the Florida Department of Environmental Protection (FDEP), the University of Florida Institute of Food and Agricultural Sciences (UF/IFAS), and other parties. The BMP educational program, delivered primarily by UF/IFAS extension in partnership with the FDEP, began in 2003 as a voluntary program. As a result of increasing concerns regarding lawn fertilization and potential harmful effects on ground and surface waters, several local governments throughout the state require commercial fertilizer applicators to have a certificate of completion in a BMP educational program. The BMP program emphasizes appropriate fertilization practices to reduce nonpoint source pollution, including proper rates, timings, and application of fertilizers. Research done on fate of fertilizer applied to turfgrass demonstrates that a properly maintained lawn provides an effective means for uptake of nutrients. Some of the factors that have been shown through research to increase the opportunity for nutrient leaching include nitrogen $(\mathrm{N})$ application at higher than recommended rates, excess rainfall after fertilization, and fertilization at a time when turf is not actively growing. Research results vary regarding $\mathrm{N}$ source and the difference in nitrate leaching resulting from $\mathrm{N}$ source. To provide concise research-based information for lawmakers and elected officials in Florida, there is currently a large research project underway to further quantify nutrient leaching under a variety of circumstances. Results of this research should form the basis for future regulations regarding fertilizer applications.

$\mathrm{V}$ oluntary best management practices (BMPs) for Florida's green industries (lawn care, landscape, and pest control industries) have been in place for residential and commercial lawn care for a number of years in Florida. These BMPs were developed in 2002 by the Florida Department of Environmental Protection, the University of Florida Institute of Food and Agricultural Sciences, the lawn care and pest control industries, Water Management Districts, environmental advocacy groups, and others as part of a larger mandated effort to reduce nonpoint source pollution. An educational program began in 2003 conducted primarily by the University of Florida Institute of Food and Agricultural Sciences (UF/IFAS) extension and supported by the Florida Department of Environmental Protection (FDEP). The BMP Educational Program consists of $\approx 6 \mathrm{~h}$ of training followed by

${ }^{1}$ Environmental Horticulture Department, University of Florida, P.O. Box 110675, Gainesville, FL 32611

${ }^{2}$ Soil and Water Science Department, University of Florida, Gainesville, FL 32611

${ }^{3}$ Corresponding author. E-mail: letr@ufl.edu. a posttest. Class participants who receive a score of $75 \%$ on the test receive a certificate of completion in the BMPs, showing that they have successfully completed the training.

Recommended BMPs for lawn and landscape care cover appropriate fertilization practices, including timing, rates, delivery method, nitrogen (N) sources, fertilizer storage, and so on. Other BMP components include plant selection, soil testing, integrated pest management, and proper irrigation and cultural practices. Specific UF/IFAS fertilization recommendations for $\mathrm{N}$ can be found in Table $\mathrm{l}$ for the various lawn grass species used in Florida. The majority of commercial lawn care and landscape services apply fertilizer within the ranges specified in the table, generally toward the higher end for the region and turf species.
Golf course BMPs were developed in 2006 by the FDEP, UF/ IFAS, golf course superintendents, and others. These are voluntary at this time, although the Florida Department of Agriculture and Consumer Services (FDACS) Fertilizer Rule [5E-1.003, F.A.C., Labeling requirements for urban turf fertilizers (State of Florida, 2007)] requires that anyone applying fertilizer to a golf course follow the published BMPs. There is no formal education program associated with the golf course BMPs at this time.

Sod production BMPs were developed in 2007 and, unlike the previously discussed BMPs, are under the purview of FDACS because sod production is considered an agricultural operation. Growers must file a "notice of intent to implement" form with FDACS, which requires detailed recordkeeping and provides a level of presumptive compliance to growers under state law. In addition to fertilization, pest management, integrated pest management, and irrigation, the sod BMPs also cover access roads, conservation buffers, ditch construction and maintenance, flood protection, wellhead protection, and wetlands and springs protection.

In addition to BMPs, there are also a number of localized laws now in place, or proposed, to regulate fertilization of lawns in Florida. At the local government level, a number of city and county governments throughout the state began to develop local fertilizer ordinances in 2006. Some of these ordinances have now passed and are currently regulating commercial fertilizer applications to residential lawns. In the areas where these ordinances have passed, there is sometimes a dedicated code enforcement officer who monitors for a certificate of completion in the BMP Educational Program. Other local governments have no formal enforcement of the ordinances, making compliance somewhat subjective. All ordinances require that commercial fertilizer applicators have a certificate

\begin{tabular}{llll}
\hline $\begin{array}{l}\text { Units } \\
\begin{array}{l}\text { To convert U.S. to SI, } \\
\text { multiply by }\end{array}\end{array}$ & U.S. unit & SI unit & $\begin{array}{l}\text { To convert SI to U.S., } \\
\text { multiply by }\end{array}$ \\
\hline 0.4536 & $\mathrm{lb}$ & $\mathrm{kg}$ & 2.2046 \\
48.8243 & $\mathrm{lb} / 1000 \mathrm{ft}^{2}$ & $\mathrm{~kg} \cdot \mathrm{ha}^{-1}$ & 0.0205 \\
1 & $\mathrm{ppm}$ & $\mathrm{mg} \cdot \mathrm{kg}^{-1}$ & $\mathrm{l}$
\end{tabular}


Table 1. Current University of Florida interim annual nitrogen recommendations for lawn grasses (Trenholm and Unruh, 2005).

\begin{tabular}{|c|c|c|c|}
\hline Turfgrass & Scientific name & $\begin{array}{c}\text { Location } \\
\text { in Florida }\end{array}$ & $\begin{array}{c}\text { Interim nitrogen } \\
\text { recommendations } \\
\left(\mathrm{lb} / 1000 \mathrm{ft}^{2} \text { per year }\right)^{\mathrm{y}}\end{array}$ \\
\hline \multirow[t]{3}{*}{ Bahiagrass } & \multirow[t]{3}{*}{ Paspalum notatum } & Northern & $2-3$ \\
\hline & & Central & $2-4$ \\
\hline & & Southern & $2-4$ \\
\hline \multirow[t]{3}{*}{ Bermudagrass } & \multirow[t]{3}{*}{ Cynodon dactylon } & Northern & $3-5$ \\
\hline & & Central & $4-6$ \\
\hline & & Southern & $5-7$ \\
\hline \multirow[t]{3}{*}{ Centipedegrass } & \multirow[t]{3}{*}{ Eremochlua ophiuroides } & Northern & $1-2$ \\
\hline & & Central & $2-3$ \\
\hline & & Southern & $2-3$ \\
\hline \multirow[t]{3}{*}{ St. augustinegrass } & \multirow[t]{3}{*}{ Stenotaphrum secundatum } & Northern & $2-4$ \\
\hline & & Central & $2-5$ \\
\hline & & Southern & $4-6$ \\
\hline \multirow[t]{3}{*}{ Zoysiagrass } & \multirow[t]{3}{*}{ Zoysia japonica } & Northern & $3-5$ \\
\hline & & Central & $3-6$ \\
\hline & & Southern & $4-6$ \\
\hline
\end{tabular}

${ }^{2}$ Northern Florida is defined as anything north of Ocala, FL; central Florida is from Ocala south to State Route 60 southern Florida is anything below State Route 60

y Homeowner preferences for lawn quality and maintenance level will vary; therefore, we recommend a range of fertility rates for each grass and location. Additionally, effects within a localized region (i.e., microenvironmental influences such as shade, drought, soil conditions, and irrigation) will necessitate that a range of fertility rates be used. These recommendations assume that grass clippings are left on the lawn $\left(\mathrm{llb} / 1000 \mathrm{ft}^{2}=48.8243 \mathrm{~kg} \cdot \mathrm{ha} \mathrm{a}^{-1}\right)$.

of completion in the existing BMP Education Program.

Some of the contentious issues in many local fertilizer ordinances include a fertilizer blackout period for a 4- or 5-month period during summer months, during which time application of $\mathrm{N}$ and phosphorus $(\mathrm{P})$ is prohibited. Other controversial points include the size of the untreated buffer zone around water bodies and requirements for use of slow-release $\mathrm{N}$ (SRN) sources.

Other current political issues regarding fertilization include legislative bills (SB 2352 and HB 1267-Urban/ Residential Environments and Water) that did not pass in the 2008 legislative session. These bills would have required BMP certification for anyone who applies fertilizer commercially statewide. The bill also contained a provision for a fertilizer license to be issued by FDACS on certification in the BMPs. A similar bill is expected to be introduced again in the coming year.

Florida also saw its first statewide regulation of fertilizer labeling in 2007. The FDACS Urban Turf Fertilizer Rule became rule as of 31 Dec. 2007. This rule regulates labeling of any fertilizer sold for use on lawns or urban turf and requires that labeled rates for $\mathrm{N}$ and $\mathrm{P}$ be followed. This rule is effective on specialty fertilizer bags (those weighing $49 \mathrm{lb}$ or less) and therefore primarily impacts fertilizer products sold to the retail homeowner market. This rule also requires the commercial lawn care industry to follow the green industry BMPs.

With these increased concerns regarding lawn fertilization, research and science-based BMPs should provide the basis for any regulations. To further assess BMP recommendations, FDEP-funded research is currently underway to quantify nutrient leaching in three locations statewide and to verify the existing BMPs. Results from this research may also assist in providing recommendations for some of the proposed local or state laws.

Previous research, both in Florida and in other states, has been conducted on nutrient leaching or runoff from turfgrass. Issues addressed include fertilization timing, $\mathrm{N}$ sources, and rates with regard to turfgrass quality and growth and $\mathrm{N}$ leaching. Other research has investigated $\mathrm{P}$ leaching characteristics and turfgrass $P$ requirements. The remainder of this article attempts to summarize some of the nutrient leaching research that should be considered by any authorities proposing state or local fertilization laws.

Trenholm and Unruh (2007) observed that the current recommended fertilization rates provided best aesthetic quality, vigor, and physiological functioning in st. augustinegrass (Stenotaphrum secundatum) in central and northern Florida. They observed that higher rates of $\mathrm{N}$ were required to maintain acceptable health and appearance of st. augustinegrass under low maintenance conditions, where irrigation and mowing regimes throughout the growing season did not follow UF/IFAS recommendations. Where maintenance practices followed UF/ IFAS recommendations, acceptable health and appearance of st. augustinegrass could be maintained with a medium $\mathrm{N}$ rate.

Other research has shown that turfgrass accumulates the largest quantity of nutrients during the time of most active growth, which is strongly influenced by day length (Sartain, 2010). This nutrient uptake is associated with vigorous root growth during the summer months, allowing for maximum nutrient uptake. In another study, Sartain (2002) reported limited root mass in warm-season grasses in early spring as grasses come out of dormancy with maximum root mass recorded from May through August. These data would suggest that fertilization of turfgrass should not be limited during summer months as is advocated in many local fertilizer ordinances. In addition, the author noted that lack of nutrition during the active growing period for warmseason grasses may cause loss of grass stand, increased weed infestation, soil erosion, and other problems that may contribute to increased nutrient runoff.

Support for summer fertilizer bans has come largely from concern for increased nutrient leaching potential when heavy summer rains are possible. Some reports have demonstrated a correlation between nutrient leaching and excessive irrigation or rainfall (Bowman et al., 1998; Morton et al., 1988; Snyder et al., 1984), whereas others report the strong ability of turfgrass to take up applied fertilizer. In southern Florida, Erickson et al. (2001) reported higher nitrate runoff under extreme hurricane conditions than from dry conditions from st. augustinegrass turf growing on a $10 \%$ slope. The authors reported, however, that the concentration of $\mathrm{N}$ in the runoff water was reported to be lower than that in natural rainfall. Quiroga-Garza et al. (2001) concluded that proper timing 
(during active growth) of quickrelease $\mathrm{N}(\mathrm{QRN})$ sources could limit nitrate leaching and that QRN sources, when applied at appropriate rates and with proper irrigation practices, resulted in limited nitrate movement during times of active grass growth.

Maintenance of a healthy turfgrass stand through proper fertilization and other cultural practices has been shown to minimize environmental impact. Erickson et al. (2001) demonstrated minimal leaching of nitrate in st. augustinegrass. Leaching losses averaged $0.1 \mathrm{lb} / 1000 \mathrm{ft}^{2} \mathrm{~N}$ from st. augustinegrass sod fertilized at $6 \mathrm{lb} / 1000 \mathrm{ft}^{2} \mathrm{~N}$ per year, whereas a mixed landscape planting lost an average of $1 \mathrm{lb} / 1000 \mathrm{ft}^{2} \mathrm{~N}$ after receiving $3 \mathrm{lb} / 1000 \mathrm{ft}^{2} \mathrm{~N}$ per year. Similar results were noted by Saha et al. (2007) in a greenhouse tub study. Research has shown that residential turfgrass can accumulate at least $1 \mathrm{lb} / 1000 \mathrm{ft}^{2}$ $\mathrm{N}$ in a 30-d period when applied in a soluble form without a negative environmental impact on subsurface water quality (Sartain, 2010). Bowman et al. (2002) found that 'Floratam' st. augustinegrass had greatest nitrate uptake of six warm-season grasses tested, whereas 'Meyer' zoysiagrass (Zoysia japonica) accumulated the lowest amount of nitrate.

The majority of local fertilizer ordinances in Florida limit $\mathrm{N}$ source by requiring that a high percentage of $\mathrm{N}$ used in lawn care $(50 \%$ to $75 \%)$ must be from a SRN source for any fertilizer application. Some research data support the concept that SRN sources will leach less. Easton and Petrovic (2004) found increased nitrate losses from plots receiving soluble N sources. Brown et al. (1982) reported increased nitrate leached from plots receiving $\mathrm{QRN}$ on greens planted to 'Tifdwarf' bermudagrass (Cynodon dactylon $\times$ C. transwalensis). Guillard and Kopp (2004) found lowest nitrate leaching occurred from a SRN organic fertilizer in coolseason lawn grasses. In a greenhouse study conducted in large tubs, Saha et al. (2007) noted greater leaching from QRN sources than from SRN in st. augustinegrass. Sartain (1990) reported higher amounts of $\mathrm{N}$ leached from ammonium sulfate (AS) than from coated AS, slowrelease $\mathrm{N} /$ methylene urea fertilizer (Nutralene; Agrium, Calgary, Alberta, Canada), and isobutyledene diurea
(IBDU). Application of Nutralene resulted in urea $\mathrm{N}$ being leached soon after application, but the total amount of $\mathrm{N}$ leached over the 112-d period was less than from AS. In another study (Sartain, 1992), the author found that coated AS leached $\approx 50 \%$ less $\mathrm{N}$ than soluble AS.

Conversely, Mancino and Troll (1990) reported no differences in nitrate leaching from 'Penncross' creeping bentgrass (Agrostis palustris, A. stolonifera) resulting from $\mathrm{N}$ source. Quiroga-Garza et al. (2001) reported that $\mathrm{QRN}$-treated plots had lower nitrate leaching levels than SRN treatments under long-day conditions in 'Tifgreen' bermudagrass, although the trend was reversed under short-day conditions.

Park (2006) observed no difference in the quantity of $\mathrm{N}$ leached from st. augustinegrass in southern Florida as a result of $\mathrm{N}$ source. Nitrogen was applied at a rate of $1 \mathrm{lb} / 1000$ $\mathrm{ft}^{2} \mathrm{~N}$ as urea N, SCU-N, a 50:50 mixture of SCU and urea, or a 25:75 mixture of urea and IBDU.

There are limited data on fate of fertilizer during turf grow-in. Shaddox and Sartain (2001) noted that $0.03 \%$ of applied $\mathrm{N}$ was collected as runoff during establishment of sodded bermudagrass on a $10 \%$ slope. Nitrate leached ranged from $8 \%$ to $12 \%$ of applied N. The plots received irrigation at a rate twice that of the water lost to evapotranspiration. In a sod production setting, Barton et al. (2006) reported that irrigation was a larger factor than $\mathrm{N}$ rate in $\mathrm{N}$ leaching during bermudagrass production.

Leaching may occur when fertilizer is applied at rates that exceed UF/IFAS recommendations (Cisar et al., 2007). Leaching rates for $\mathrm{N}$ applied to established 'Floratam' st. augustinegrass accounted for $5 \%$ to $16 \%$ of the applied N. Nitrogen was applied as soluble urea.

Nitrate leaching has also been evaluated with applications of granular versus liquid fertilizer. Gross et al. (1990) found no difference in nitrate leaching between treated tall fescue (Festuca arundinacea) and kentucky bluegrass (Poa pratensis) receiving urea as either a granular or liquid application. Unfertilized control plots leached less nitrate than did treated plots.

Phosphorus is not usually a limiting factor for established nonathletic turfgrass maintenance in Florida, although the FDACS fertilizer rule applies stringent limits on its use. Phosphorus fertilization is most essential during early establishment of the turfgrass because it influences rooting. After establishment, most turfgrasses can survive on low levels of fertilizer P. Phosphorus fertilization is not recommended for st. augustinegrass in sandy soils if soil Mehlich- 1 is greater than $10 \mathrm{mg} \cdot \mathrm{kg}^{-1}$ P (Liu et al., 2007).

Soil testing is recommended in the BMP Educational Program for all home lawns or turf sites to determine if additional $\mathrm{P}$ may be needed. Research by Liu et al. (2008) provided guidelines for the statewide fertilizer labeling rule, which allows no more than 0.25 $\mathrm{lb} / 1000 \mathrm{ft}^{2} \mathrm{P}$ per application. This $\mathrm{P}$ rate is based on minimum $P$ fertilization required to maintain a minimum tissue $\mathrm{P}$ concentration of $0.16 \%$.

As a result of concerns of nonpoint source pollution, turfgrass fertilization is under increasing scrutiny in Florida. There are numerous local fertilizer ordinances in effect, which are not always based on research results, and the potential exists for statewide regulation of commercial fertilizer applicators. An ongoing collaborative educational program has been underway since 2003 to provide education and certificates of completion in BMP practices for the green industries. Past and current research on nutrient leaching from turfgrass demonstrates that current Florida turfgrass fertilization recommendations are valid agronomically and environmentally.

\section{Literature cited}

Barton, L., G.G.Y. Wan, and T.D. Colmer. 2006. Turfgrass (Cynodon dactylon L.) sod production on sandy soils: II. Effects of irrigation and fertilizer regimes on N leaching. Plant Soil 284:147-164.

Bowman, D.C., C.T. Cherney, and T.W. Rufty. 2002. Fate and transport of nitrogen applied to six warm-season turfgrasses. Crop Sci. 42:833-841.

Bowman, D.C., D.A. Devitt, M.C. Engelke, and T.W. Rufty. 1998. Root architecture affects nitrate leaching from bentgrass turf. Crop Sci. 38:1633-1639.

Brown, K.W., J.C. Thomas, and R.L. Duble. 1982. Nitrogen source effect on nitrate and ammonium leaching and run 
off losses from greens. Agron. J. 74:947950 .

Cisar, J.L., L.E. Trenholm, and J.B. Unruh. 2007. FDEP WM869, Warm season turfgrass $\mathrm{N}$ rates and irrigation $\mathrm{BMP}$ verification, Year 1 report. Florida Dept. Environ. Protection, Tallahassee, FL.

Easton, Z.M. and A.M. Petrovic. 2004. Fertilizer source effect on ground and surface water quality in drainage from turfgrass. J. Environ. Qual. 33:645-655.

Erickson, J.E., J.L. Cisar, J.C. Volin, and G.H. Snyder. 2001. Comparing nitrogen runoff and leaching between newly established st. augustinegrass turf and an alternative residential landscape. Crop Sci. 41:1889-1895.

Gross, C.M., J.S. Angle, and M.S. Welterlen. 1990. Nutrient and sediment losses from turfgrass. J. Environ. Qual. 19:663-668.

Guillard, K. and K.L. Kopp. 2004. Nitrogen fertilizer form and associated nitrate leaching from cool-season lawn turf. J. Environ. Qual. 33:1822-1827.

Liu, M., J.B. Sartain, L.E. Trenholm, and G.L. Miller. 2007. St. augustinegrass phosphorus requirement growing in sandy soils. Crop Sci. 47:165-169.

Liu, M., J.B. Sartain, L.E. Trenholm, and G.L. Miller. 2008. Phosphorus requirements of st. augustinegrass grown in sandy soils. Crop Sci. 48:1178-1186.
Mancino, C.F. and J. Troll. 1990. Nitrate and ammonium leaching losses from $\mathrm{N}$ fertilizers applied to 'Penncross' creeping bentgrass. HortScience 25:194-196.

Morton, T.G., A.J. Gold, and W.M. Sullivan. 1988. Influence of overwatering and fertilization on nitrogen losses from home lawns. J. Environ. Qual. 17:124-130.

Park, D.M. 2006. Nitrogen leaching and st. augustinegrass turf response to lawn maintenance strategies. PhD Diss., Univ. Florida, Gainesville, FL.

Quiroga-Garza, H.M., G.A. Picchioni, and M.D. Remmenga. 2001. Bermudagrass fertilized with slow-release nitrogen sources. I. Nitrogen uptake and potential leaching losses. J. Environ. Qual. 30:440448.

Saha, S.K., L.E. Trenholm, and J.B. Unruh. 2007. Effect of fertilizer source on nitrate leaching and st. augustinegrass turfgrass quality. HortScience 42:14781481 .

Sartain, J.B. 1990. Leaching studies involving selected slow-release N sources. Univ. Florida, Annu. Turfgrass Rpt. p. 77-83.

Sartain, J.B. 1992. Relative nitrogen leaching losses from selected slow-release N sources. Univ. Florida, Annu. Turfgrass Rpt. p. 131-136.
Sartain, J.B. 2002. Tifway bermudagrass response to potassium fertilization. Crop Sci. 42:507-512.

Sartain, J.B. 2010. Comparative influence of $\mathrm{N}$ source on leaching of $\mathrm{N}$ and st. augustinegrass quality, growth and $\mathrm{N}$ uptake. Soil Crop Sci. Soc. Florida Proc. 69 (in press).

Shaddox, T.W. and J.B. Sartain. 2001. Fate of nitrogen during grow-in of a golf course fairway under different nitrogen management practices. Soil Crop Sci. Soc. Florida Proc. 60:59-63.

Snyder, G.H., B.J. Augustin, and J.M. Davidson. 1984. Moisture sensor controlled irrigation for reducing nitrogen leaching in bermudagrass turf. Agron. J. 76:964-969.

State of Florida. 2007. 5E-1.003. Florida Administrative Code. Labeling requirements for urban turf fertilizers. 17 Mar. 2009. <https://www.flrules.org/gateway/ ruleNo.asp? $\mathrm{ID}=5 \mathrm{E}-1.003>$.

Trenholm, L.E. and J.B. Unruh. 2005. The Florida lawn handbook, 3rd Ed. University Press of Florida, Gainesville, FL.

Trenholm, L.E. and J.B. Unruh. 2007. St. augustinegrass fertilizer trials. J. Plant Nutr. 30:453-461. 